\title{
Can combine headers and travel speeds affect the quality of soybean harvesting operations?
}

\author{
Patricia C. de Menezes ${ }^{1}$, Rouverson P. da Silva², Franciele M. Carneiro ${ }^{2}$, \\ Lucas A. da S. Girio², Mailson F. de Oliveira ${ }^{2}$ \& Murilo A. Voltarelli ${ }^{3}$ \\ ${ }^{1}$ Instituto Federal de Educação, Ciência e Tecnologia de Rondônia. Colorado do Oeste, RO. E-mail: patricia.menezes@ifro.edu.br (Corresponding \\ author) - ORCID: 0000-0002-5570-0405 \\ ${ }^{2}$ Universidade Estadual Paulista/Faculdade de Ciências Agrárias e Veterinárias/Departamento de Engenharia Rural. Jaboticabal, SP. E-mail: \\ rouverson@gmail.com - ORCID: 0000-0001-8852-2548; franmorlin1@gmail.com - ORCID: 0000-0003-0117-7468; lucas_girio@hotmail.com - \\ ORCID: 0000-0002-2383-9779; mailsonagronomia@gmail.com - ORCID: 0000-0003-4771-0424 \\ ${ }^{3}$ Universidade Federal de São Carlos/Centro de Ciências da Natureza/Campus Lagoa do Sino. Buri, SP. E-mail: voltarelli.ufscar@gmail.com - ORCID: \\ 0000-0002-3774-1705
}

\section{Key words:}

statistical process control

harvester

Glycine max

losses

combine header

\begin{abstract}
A B S T R A C T
Assuring the quality of mechanical soybean harvesting is crucial to ensure that investment in other stages of crop production is converted into profit for the farmer. Because the quality of this operation is related to decreased losses, which may be affected by the combine header used and by the harvesting speed, the aim of the present study was to assess the quality of mechanical soybean harvesting in the Southern Cone of Rondônia, using harvesters with different combine headers and travel speeds via statistical process control. The experiment was performed during the 2015/16 harvest in an agricultural area of the municipality of Cabixi, RO, located at the geographical coordinates $13^{\circ} 27^{\prime} \mathrm{S}$ and $60^{\circ} 41^{\prime} \mathrm{W}$. The study was designed based on the premises of the statistical process control, sampling 80 points $100 \mathrm{~m}$ apart. Combine header, internal, total, and cutting height losses were assessed. Quality of the harvesting process was assessed using the draper header. Travel speed had little effect on process quality. Crop losses were higher than the acceptable limit, indicating the need to improve the process.
\end{abstract}

\section{Palavras-chave:}

controle estatístico de processo colhedora

Glycine max

perdas

plataforma de corte

\section{Plataformas de corte e velocidades podem afetar a qualidade da operação de colheita de soja?}

\begin{abstract}
R E S U M O
A qualidade da colheita mecanizada de soja é essencial para garantir que todo investimento realizado nas demais etapas do processo produtivo da cultura seja convertido em lucro para o produtor. Considerando que a qualidade dessa operação está relacionada com menores perdas e que a plataforma de corte utilizada e a velocidade de colheita podem influenciar nisso, objetivou-se avaliar a qualidade da colheita mecanizada da soja, no Cone Sul de Rondônia, em colhedoras com diferentes plataformas de corte e velocidades de deslocamento por meio do controle estatístico de processo. O experimento foi realizado na safra 2015/16 em uma área agrícola no município de Cabixi, RO, localizada nas coordenadas geográficas $13^{\circ} 27^{\prime} \mathrm{S}$ e $60^{\circ} 41^{\prime} \mathrm{W}$. O delineamento experimental foi estabelecido de acordo com as premissas do controle estatístico de processo, sendo amostrados 80 pontos distanciados a cada $100 \mathrm{~m}$. Avaliaram-se as perdas na plataforma, nos mecanismos internos e totais e a altura de corte. A melhor qualidade do processo de colheita foi obtida na plataforma de esteira, com pouca influência da velocidade de deslocamento. O nível de perdas na colheita foi acima do limite aceitável, indicando necessidade de melhorias do processo.
\end{abstract}




\section{INTRODUCTION}

Harvesting must be high-quality and efficient to ensure that investments during production are converted into profit, because this is the final agricultural operation in the field, and is conducted over a short period of time. Production losses often occur during this process (Loureiro Júnior et al., 2014), and they may be affected by several characteristics of the harvester and the field conditions (Toledo et al., 2008).

Methods for monitoring losses in harvesting operations may generate data that help to reduce production losses (Chioderoli et al., 2012). Of these methods, statistical process control (SPC) has been used to monitor agricultural processes in mechanical soybean harvesting (Chioderoli et al., 2012; Compagnon et al., 2012; Loureiro Júnior et al., 2014; Paixão et al., 2017), peanut sowing (Santos et al., 2017), and mechanical sugarcane fertilization (Carneiro et al., 2017).

However, few studies have applied SPC to monitor mechanical soybean harvesting losses as a function of combine header type because they may account for $80-85 \%$ of losses (Cunha \& Zandbergen, 2007).

The area under soybean production has been increasing in Rondônia, and soybean is considered one of the main agricultural products of the state. Therefore, the quality of agricultural operations must be controlled to ensure increased efficiency and profitability. Because the use of the combine header and the harvesting speed may affect the quantity of operational losses, the aim of this study was to assess the quality of mechanical soybean harvesting in the Southern Cone of Rondônia, performed using two types of combine header and two speeds, using cutting height and harvesting losses as quality indicators.

\section{Material AND Methods}

The experiment was conducted in the municipality of Cabixi, RO in an agricultural area located at the geographical coordinates $13^{\circ} 27^{\prime} \mathrm{S}$ and $60^{\circ} 41^{\prime} \mathrm{W}$, during the 2015/16 harvest. The average altitude was $208 \mathrm{~m}$, and the climate was defined as Am, according to the Köppen climate classification (Alvares et al., 2013). The soybean cultivar P98Y12 was planted in the experimental area and generated a mean crop yield of $3.781 \mathrm{~kg} \mathrm{ha}^{-1}$.

Two Massey Ferguson combine harvesters, model MF 9790, with an axial flow threshing system, $261 \mathrm{~kW}$ (355 hp) engine power rating, and $10.570 \mathrm{~L}$ grain tank capacity, were used to monitor mechanical soybean harvesting losses. The combine harvesters were equipped with a $10.7 \mathrm{~m}$ (35 feet) powerflex draper header and a $9.1 \mathrm{~m}$ (30 feet) screw conveyor (auger). Two travel speeds were used, V1: $6 \mathrm{~km} \mathrm{~h}^{-1}$ and V2: $8 \mathrm{~km} \mathrm{~h}^{-1}$.

The study was designed according to the basic premises of SPC. Samples were collected over time at two points in the field, $100 \mathrm{~m}$ apart, at each passage of the combine harvester header, totaling 80 points (40 points for each machine). The following quality indicators were assessed in the field: cutting height, combine header, internal and total losses.

Four circular frames (A, B, C, and D), totaling an area of $1.0 \mathrm{~m}^{2}$, were used to determine the harvesting losses. The circular frames were dropped to the ground immediately after the passage of the combine harvester header, positioned along the width of the combine harvester. Grains and pods found in the circular frames were collected; those found under the frame were considered header losses, and those found over the frame were considered internal losses. Total losses were calculated by adding the previous losses, disregarding natural losses, which were assessed at 10 points in an area of $2 \mathrm{~m}^{2}$. The effective cutting height was measured using a ruler.

The results were analyzed by descriptive statistics for general data analyses, and normality was assessed using the Ryan-Joiner test. Individuals and moving range control charts were used to assess the quality of the soybean harvest.

The mean losses in each circular frame (A, B, C, and D) were presented separately in the individual control charts for combine header and internal losses to assess the distribution of losses along the width of the combine header.

Specific upper and lower limits of 0 and $1.5 \%$, respectively, were set in the total losses chart, based on a tolerable level of losses of $60 \mathrm{~kg} \mathrm{ha}^{-1}$ (EMBRAPA, 2017) and on the mean crop yield of the study area.

\section{Results AND Discussion}

Standard deviation (SD) and coefficient of variation (CV; Table 1) analysis shows the data dispersion or variability. According to the classification by Gomes \& Garcia (2002), the $\mathrm{CV}$ of the present study was high, possibly due to the effects of harvester, climate, plant, and soil factors, which cause high variability during data collection. High CV values have been observed by other researchers (Campos et al., 2005; Holtz \& Reis, 2013; Silva et al., 2013; Loureiro Júnior et al., 2014; Cassia et al., 2015) and suggest the need for a classification that considers the specificities of the agricultural area, particularly with respect to agricultural mechanization.

The coefficients of skewness were moderate to high, according to Tavares et al. (2015), for all study variables except for cutting height with a draper header at a speed of $8 \mathrm{~km} \mathrm{~h}^{-1}$. Most quality indicators showed positive asymmetry (to the right), thus indicating data concentration at the lowest values. This type of asymmetry is interesting in the case of harvesting losses, because it indicates that, despite the asymmetry, the losses are concentrated in values close to and/or lower than the mean and are therefore acceptable.

Control chart analysis showed that the mean effective cutting height ranged from 8.15 to $9.06 \mathrm{~cm}$ (Figure 1), which is within the limits considered ideal for mechanical harvesting by cutting below the insertion of the first pod, which, in the present study, had a mean height of $10.5 \mathrm{~cm}$. This mean height was lower than that observed by Ormond et al. (2015) at $10.84 \mathrm{~cm}$, who used a combine header with a lower technological level (5 m, rigid header), demonstrating that the type of header used may affect the cutting height and, therefore, the operational quality.

This indicator indicated better process quality when using the draper header because, at both speeds, the draper header showed lower variability and higher stability. The screw conveyor presented the highest variability at a speed of $8 \mathrm{~km} \mathrm{~h}^{-1}$, 
Table 1. Descriptive statistics for cutting height, header, and internal and total losses as a function of combine header and travel speed

\begin{tabular}{|c|c|c|c|c|c|c|c|c|c|c|}
\hline Quality indicators & Header & $\begin{array}{c}\mathrm{S} \\
\left(\mathrm{km} \mathrm{h}^{-1}\right)\end{array}$ & M & Med & CV & $\sigma$ & Cs & Ck & RJ & $\mathbf{P}$ \\
\hline \multicolumn{11}{|c|}{ Header losses (\%) } \\
\hline \multirow{4}{*}{ Header losses } & & 1 & 3.43 & 3.05 & 77.98 & 2.70 & 1.32 & 1.11 & 0.919 & $<0.01^{\mathrm{A}}$ \\
\hline & Screw conveyor & ॥ & 2.17 & 1.83 & 68.15 & 1.48 & 1.42 & 1.97 & 0.932 & $0.02^{A}$ \\
\hline & & I & 1.82 & 1.30 & 69.59 & 1.27 & 0.92 & -0.59 & 0.926 & $<0.01^{A}$ \\
\hline & Draper header & ॥I & 1.23 & 0.99 & 105.06 & 1.30 & 3.38 & 13.17 & 0.760 & $<0.01^{\mathrm{A}}$ \\
\hline \multicolumn{11}{|c|}{ Internal losses (\%) } \\
\hline \multirow{4}{*}{ Internal losses } & & 1 & 0.95 & 0.60 & 88.69 & 0.84 & 1.55 & 1.48 & 0.882 & $<0.01^{\mathrm{A}}$ \\
\hline & Screw conveyor & $\|$ & 1.48 & 1.13 & 62.08 & 0.92 & 1.19 & 1.75 & 0.943 & $0.04^{A}$ \\
\hline & & 1 & 0.82 & 0.73 & 63.22 & 0.52 & 1.65 & 3.39 & 0.921 & $<0.01^{\mathrm{A}}$ \\
\hline & Draper header & ॥ & 1.91 & 0.59 & 181.43 & 3.47 & 2.97 & 9.28 & 0.709 & $<0.01^{\mathrm{A}}$ \\
\hline \multicolumn{11}{|c|}{ Total losses (\%) } \\
\hline \multirow{4}{*}{ Total losses } & & I & 4.38 & 3.59 & 68.70 & 3.01 & 1.18 & 1.02 & 0.936 & $0.02^{A}$ \\
\hline & Screw conveyor & \| & 3.65 & 3.19 & 54.26 & 1.98 & 1.55 & 2.76 & 0.911 & $<0.01^{A}$ \\
\hline & & 1 & 2.64 & 2.28 & 51.89 & 1.37 & 0.95 & 0.39 & 0.961 & $>0.10^{\mathrm{N}}$ \\
\hline & Draper header & ॥ & 3.15 & 1.50 & 122.40 & 3.85 & 2.53 & 7.03 & 0.789 & $<0.01^{\mathrm{A}}$ \\
\hline \multicolumn{11}{|c|}{ Cutting height $(\mathrm{cm})$} \\
\hline \multirow{4}{*}{ Cutting height } & & I & 9.08 & 8.61 & 22.14 & 2.01 & 2.51 & 8.25 & 0.860 & $<0.01^{\mathrm{A}}$ \\
\hline & Screw conveyor & II & 9.77 & 9.33 & 29.89 & 2.92 & 1.45 & 2.10 & 0.928 & $<0.01^{\mathrm{A}}$ \\
\hline & Draner header & I & 8.78 & 8.42 & 14.23 & 1.25 & 1.07 & 0.91 & 0.954 & $0.07^{A}$ \\
\hline & Uraper header & $\|$ & 8.15 & 8.08 & 12.14 & 0.99 & -0.02 & -0.23 & 0.987 & $>0.10^{\mathrm{N}}$ \\
\hline
\end{tabular}

S - Speed; M - Arithmetic mean of the sample; Med - Median; CV - Coefficient of variation; $\sigma$ - Standard deviation; Cs - Coefficient of skewness; Ck - Coefficient of kurtosis; RJ - Ryan-Joiner test for normality; P - Probability value according to the Ryan-Joiner test ( N Normal distribution; ${ }^{A}$ Non-normal distribution with $p<0.10$ )
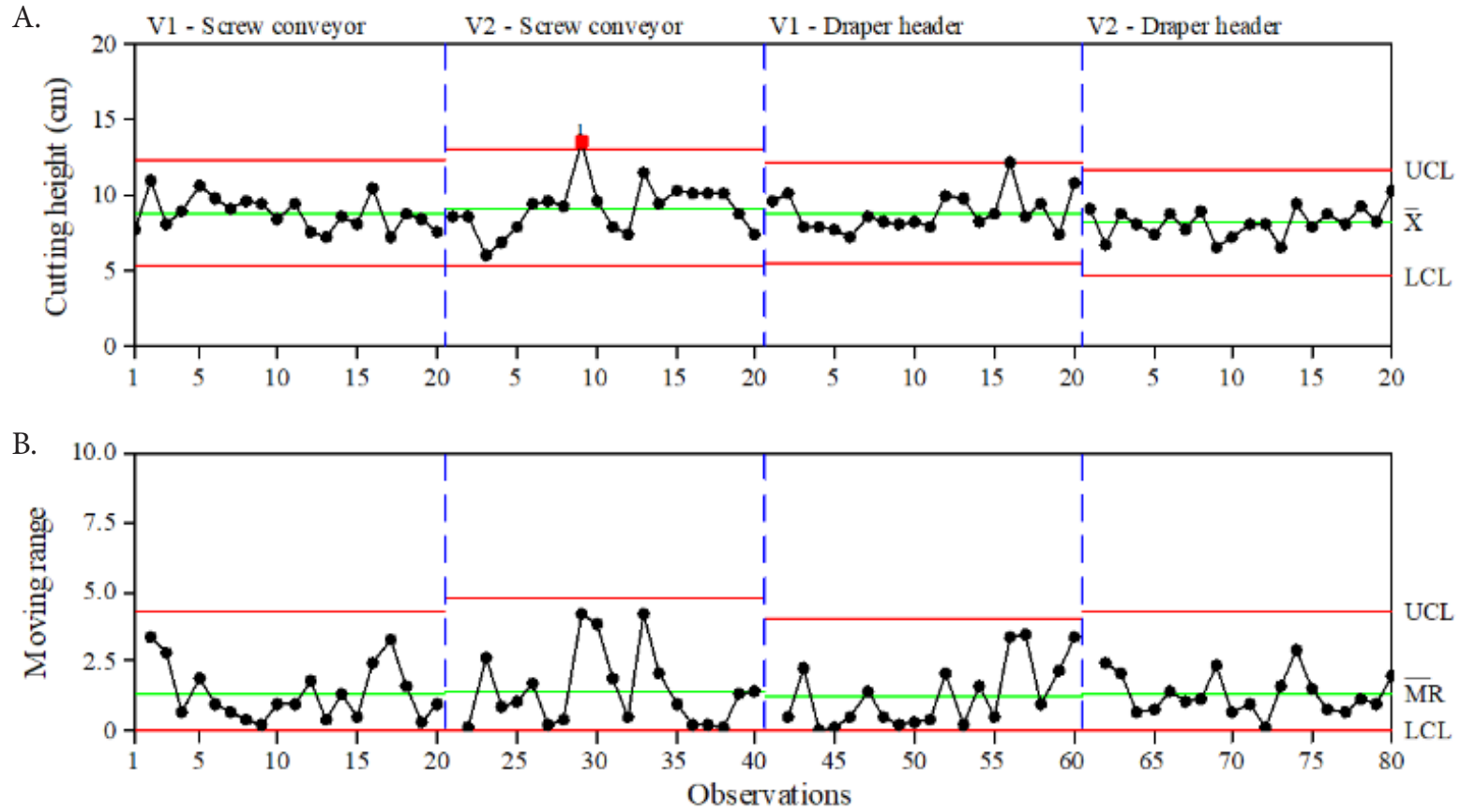

$\mathrm{V} 1=6 \mathrm{~km} \mathrm{~h}^{-1} ; \mathrm{V} 2=8 \mathrm{~km} \mathrm{~h}^{-1} ; \mathrm{UCL}$ - Upper control limit. LCL - Lower control limit. X - Mean, MR - Mean moving range

Figure 1. Individual (A) and moving range (B) control charts for cutting height as a function of combine header and speed

due to special causes. Soil irregularities occurred during the experiment, which complicated the monitoring of the combine header. In addition, the higher speed $\left(8 \mathrm{~km} \mathrm{~h}^{-1}\right)$, which requires a faster response time of the header sensors to monitor the terrain, may have contributed to this process instability, thereby adversely affecting the operational quality and increasing the level of losses.

Compagnon et al. (2012) reported that a deficiency in cutting height favored an increase in losses during mechanical soybean harvest. Toledo et al. (2008) stated that the cutting height of the header may directly affect mechanical harvesting losses.

The lowest average values of combine header losses and process variability were assessed when using the Draper header
(Figure 2). The mean screw conveyor losses were 35\% higher than the mean Draper header losses at a speed of $6 \mathrm{~km} \mathrm{~h}^{-1}$ (V1) and $51 \%$ higher at a speed of $8 \mathrm{~km} \mathrm{~h}^{-1}(\mathrm{~V} 2)$. Therefore, the Draper header provides higher stability and quality to the harvesting process even when operating at higher speeds.

The higher quality of the Draper header was also observed by Gobbi et al. (2014), who noted that the Draper header decreased losses by $40 \%$ compared with the screw conveyor. According to Nietiedt et al. (2011), this decrease in harvesting losses may be explained by the absence of friction between the pods and the screw conveyor in Draper headers. This confirms that the harvesting quality of Draper headers is higher than that of screw conveyors. 

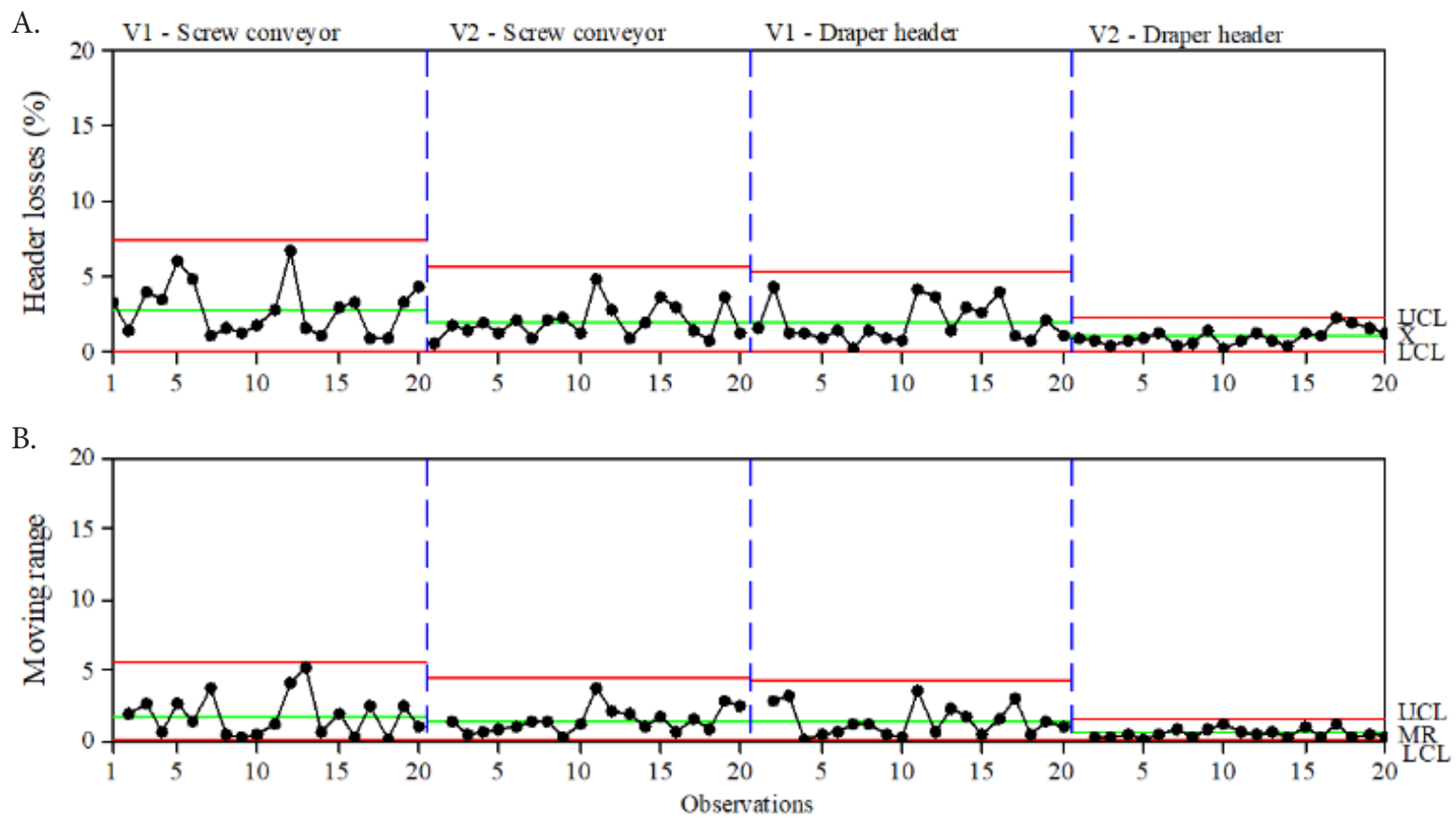

$\mathrm{V} 1=6 \mathrm{~km} \mathrm{~h}^{-1} ; \mathrm{V} 2=8 \mathrm{~km} \mathrm{~h}^{-1} ; \mathrm{UCL}$ - Upper control limit. LCL - Lower control limit. X - Mean, MR - Mean moving range

Figure 2. Individual (A) and moving range (B) control charts for header losses as a function of combine header and speed

The draper header also presented lower mean internal losses and process variability at both travel speeds compared with the screw conveyor (Figure 3). The best process quality was assessed at V1 $\left(6 \mathrm{~km} \mathrm{~h}^{-1}\right)$, with lower mean losses and without special causes.

Although an outlier was observed with the draper header at V2 $\left(8 \mathrm{~km} \mathrm{~h}^{-1}\right.$; observation number 16$)$, this had no effect on process quality, because a lower SD was observed in this chart, and therefore, a shorter distance between the mean and upper control limits.

The better process quality observed with the Draper header, in terms of internal losses, may be attributed to the higher feed rate uniformity of this header. This results in lower mass flow fluctuations, which are processed by internal mechanisms and therefore, maintain better tracking conditions, causing lower loss variability (Gobbi et al., 2014).

Thus, as shown for internal losses, an outlier was also observed for total losses (Figure 4A, B), which may be explained as described above.

The total losses ranged from 1.8 to $4.4 \%$, exceeding the upper control limit of $1.5 \%$. This limit was set based on the tolerable level of losses, which, according to EMBRAPA (2017), is up to $60 \mathrm{~kg} \mathrm{ha}^{-1}$. Considering this result, harvesting operations urgently require interventions to reduce losses and to improve the process.
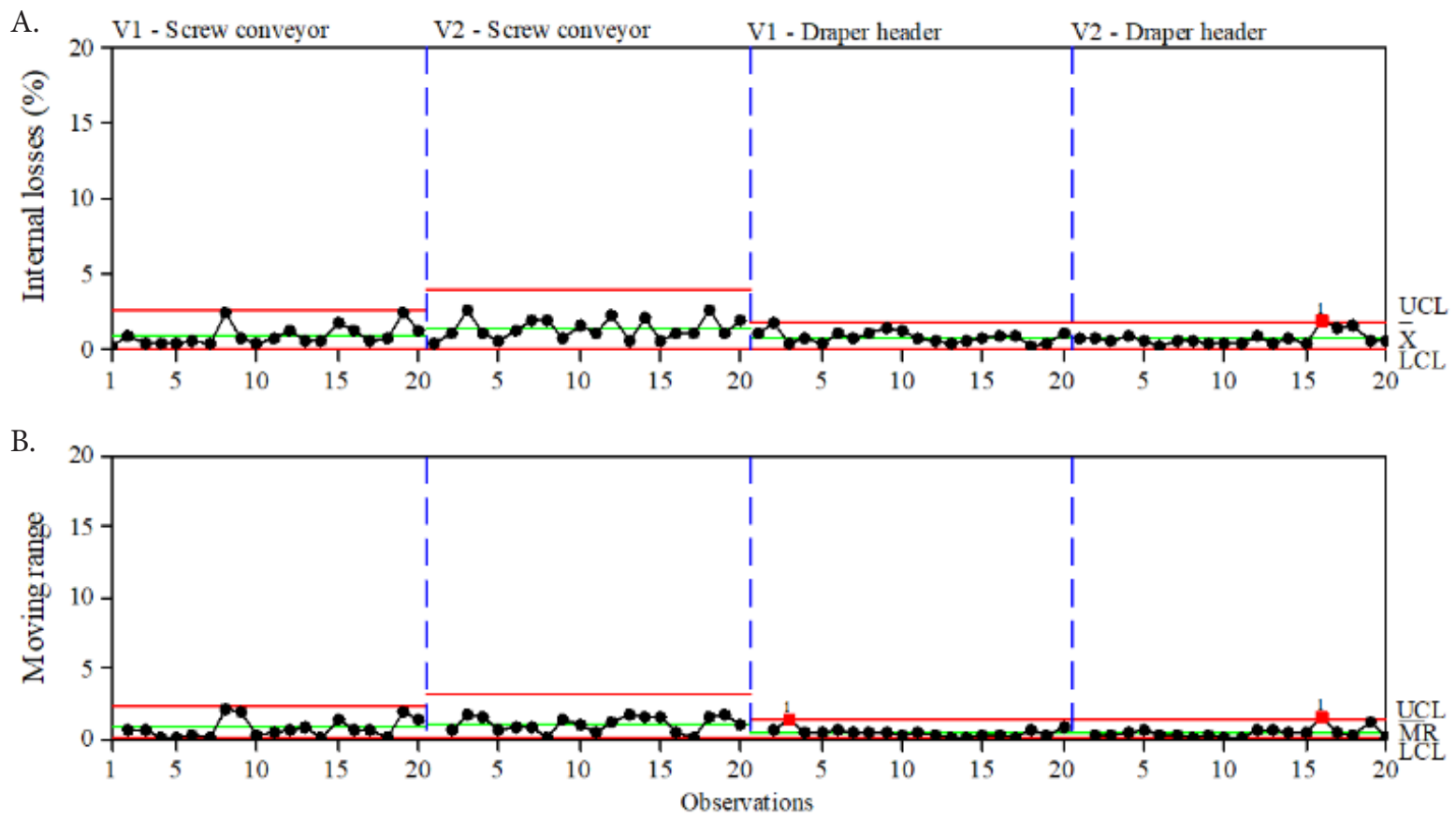

$\mathrm{V} 1=6 \mathrm{~km} \mathrm{~h}^{-1} ; \mathrm{V} 2=8 \mathrm{~km} \mathrm{~h}^{-1}$; UCL - Upper control limit. LCL - Lower control limit. X - Mean, MR - Mean moving range

Figure 3. Individual (A) and moving range (B) control charts for internal losses as a function of combine header and speed 

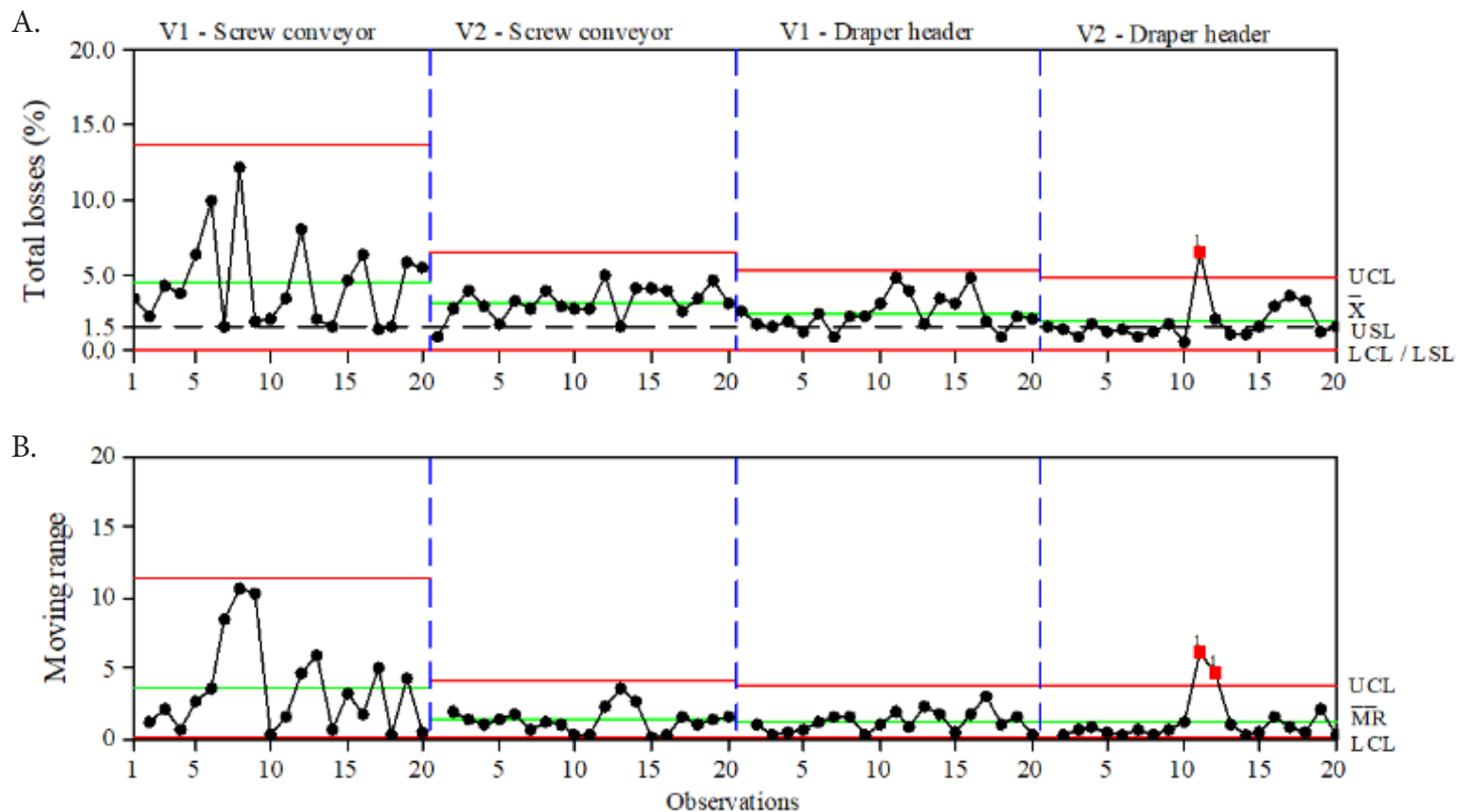

$\mathrm{V} 1=6 \mathrm{~km} \mathrm{~h}^{-1} ; \mathrm{V} 2=8 \mathrm{~km} \mathrm{~h}^{-1} ;$ UCL - Upper control limit. LCL - Lower control limit for the individual values. X - Mean, MR - Mean moving range; USL - Upper specific limit; LSL - Lower specific limit Figure 4. Individual (A) and moving range (B) control charts for total losses as a function of combine header and speed
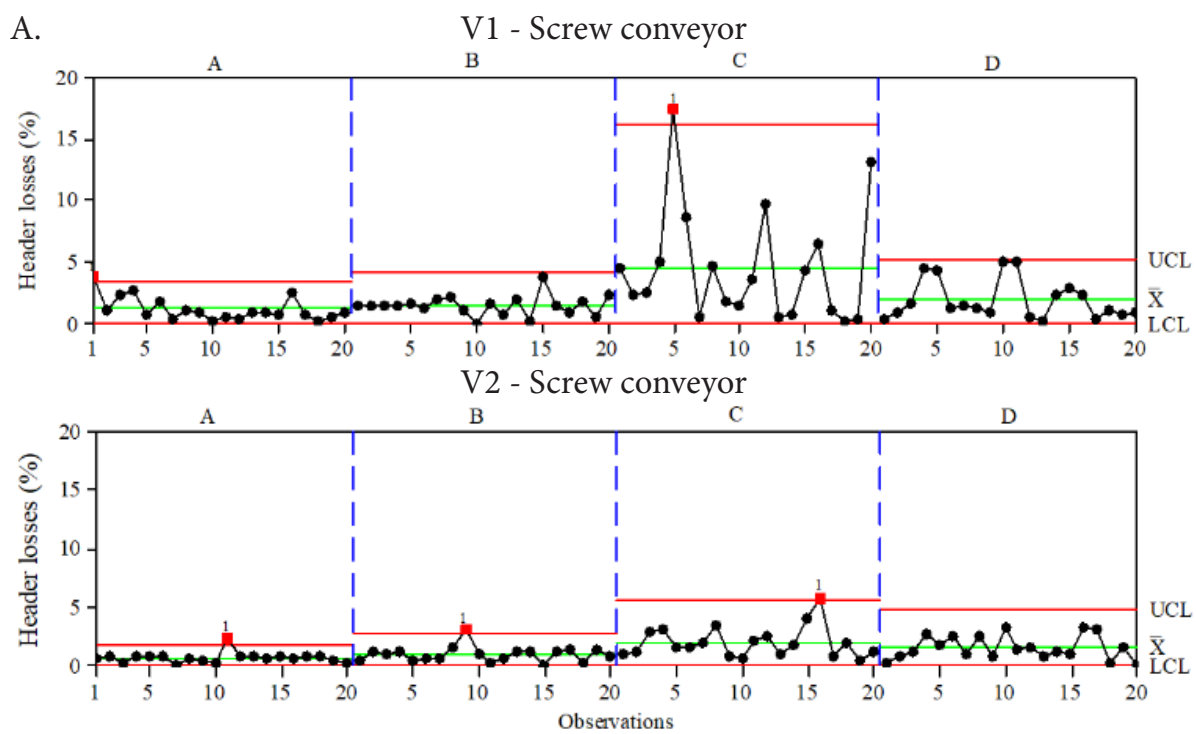

V1 - Draper header

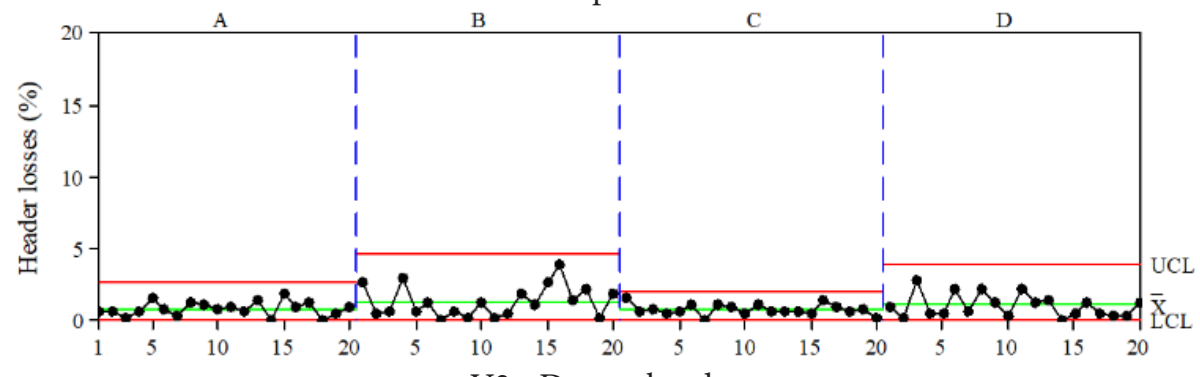

V2 - Draper header

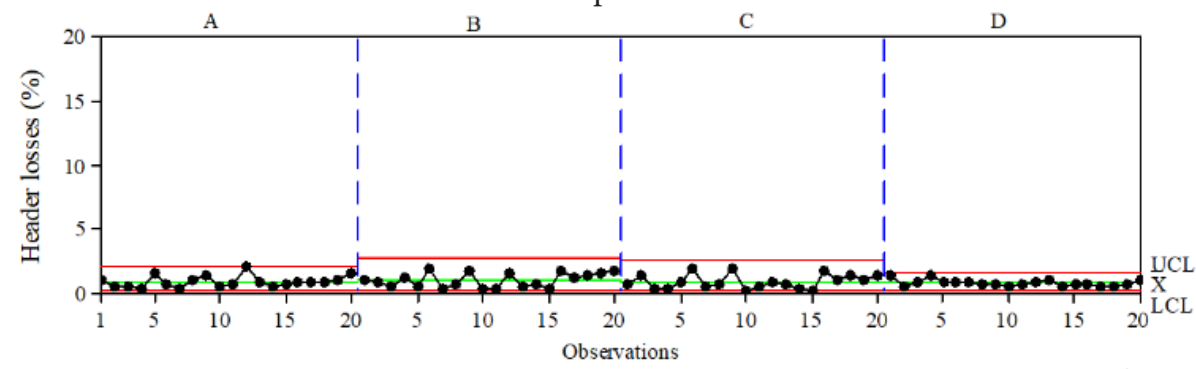

Continues on the next page 
Continued from Figure 5
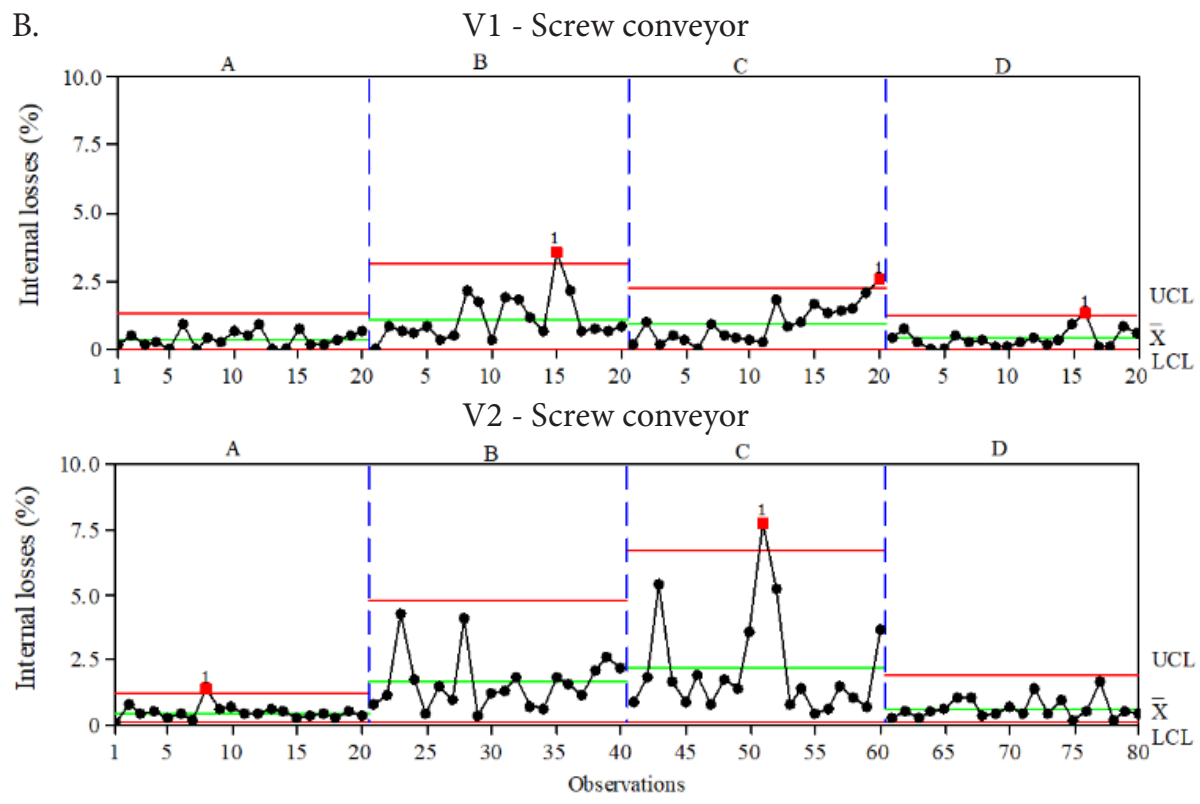

V1 - Draper header

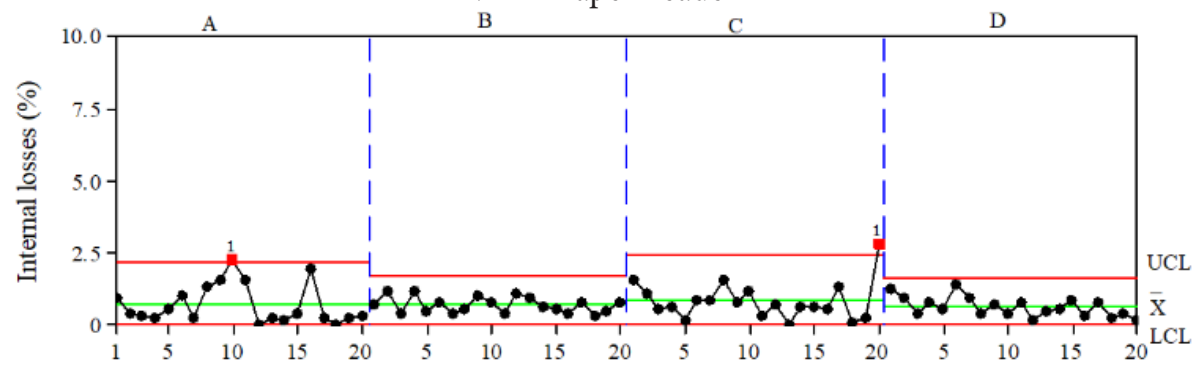

V2 - Draper header

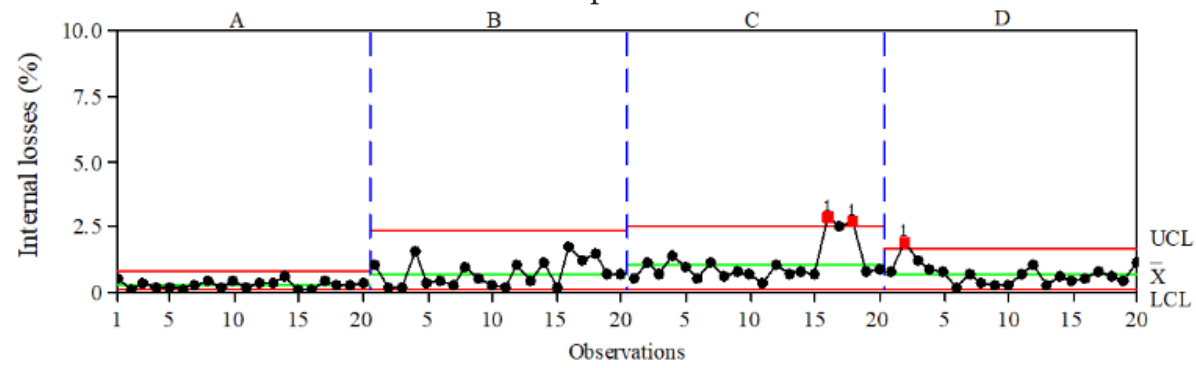

V1: $6 \mathrm{~km} \mathrm{~h}^{-1}$. V2: $8 \mathrm{~km} \mathrm{~h}^{-1}$. UCL: Upper control limit. LCL: Lower control limit. X - Mean

Figure 5. Individual control charts for header (A) and internal (B) losses as a function of the type of combine header and speed in circular frames A, B, C, and D

This improvement may be achieved by reducing header losses because they account for $70-53 \%$ of the total losses from screw conveyor and draper headers, respectively. The higher losses observed with the screw conveyor reflect the higher variability in total losses when using this type of combine header (Figure 4A ), which had points with high losses (higher than 5\%) at both V1 and V2. Although header losses had a stronger impact, corrective measures to reduce losses in internal mechanisms cannot be disregarded because the mean internal losses were also higher than the specific limit of $1.5 \%$.

The mean header losses assessed in each circular frame (Figure 5A) were higher and more variable in frame $\mathrm{C}$ with the screw conveyor, at both speeds. Outliers occurred in most frames when using this header, thus indicating the occurrence of special causes, which may be due to the way the material cut is transported to the center of the header. The contact between pods and the screw conveyor (auger) often causes grains to fall outside the header. In the present study, a large number of weeds was detected in the harvested area, which overloaded the material transported by the header, thereby causing packing owing to the way the material is transported by the screw conveyor. Transport of material by this type of header was not continuous, which may have caused the high variability in the distribution of losses.

Draper header losses were more uniform (Figure 5A). No outliers were found, thus showing process stability, and variability was lowest at $\mathrm{V} 2$. The results suggest that this type of header, even when working under adverse conditions, such as the presence of weeds and at high speeds, increases process stability and reduces losses, thereby improving the operational quality.

The internal losses in each circular frame (Figure 5B) varied with the combine header used. The highest header losses of the screw conveyor were concentrated in the center of the combine harvester, frames $\mathrm{B}$ and $\mathrm{C}$, with $73 \%$ at $\mathrm{V} 1$ and $81 \%$ at $\mathrm{V} 2$. The 
draper header losses were distributed more evenly across the combine harvester width, that is, in the four circular frames (A, B, C, and D).

Data collection using circular frames to assess harvesting losses makes it possible to assess the distribution of grain losses across combine harvesters and to indirectly assess stalk distribution. This is because the behavior of both will be similar, thereby enabling losses and function to be monitored in order to adequately adjust the controls with the ultimate aim of improving the operational quality.

\section{Conclusions}

1. The draper header showed better harvesting quality with lower mean losses and process variability.

2. Travel speed had little effect on operational quality based on the quality indicators assessed.

3. The level of harvesting losses was higher than the acceptable limit, indicating the need for improved processes.

\section{Literature Cited}

Alvares, C. A.; Stape, J. L.; Sentelhas, P. C.; Gonçalves, J. L. de M.; Sparovek, G. Köppen's climate classification map for Brazil. Meteorologische Zeitschrift, v.22, p.711-728, 2013. https://doi. org/10.1127/0941-2948/2013/0507

Campos, M. A. O.; Silva, R. P. da; Carvalho Filho, A.; Mesquita, H. C. B.; Zabani, S. Perdas na colheita mecanizada de soja no estado de Minas Gerais. Engenharia Agrícola, v.25, p.207-213, 2005. https:// doi.org/10.1590/S0100-69162005000100023

Carneiro, F. M.; Furlani, C. E. A.; Ormond, A. T. S.; Kazama, E. H.; Silva, R. P. da. Mechanized fertilization: Individual application of nitrogen, phosphorus and potassium in sugarcane. Revista Ciência Agronômica, v.48, p.278-287, 2017. https://doi.org/10.5935/18066690.20170032

Cassia, M. T.; Voltarelli, M. A.; Silva, R. P. da; Zerbato, C.; Lima, P. H. de. Monitoramento da operação de colheita mecanizada de sementes de soja. Revista Brasileira de Engenharia Agrícola e Ambiental, v.19, p.1209-1214, 2015. https://doi.org/10.1590/18071929/agriambi.v19n12p1209-1214

Chioderoli, C. A.; Silva, R. P. da; Noronha, R. H. D. F.; Cassia, M. T.; Santos, E. P. dos. Perdas de grãos e distribuição de palha na colheita mecanizada de soja. Bragantia, v.71, p.112-121, 2012. https://doi.org/10.1590/S0006-87052012005000003

Compagnon, A. M.; Silva, R. P. da; Cassia, M. T.; Graat, D.; Voltarelli, M. A. Comparação entre métodos de perdas na colheita mecanizada de soja. Scientia Agropecuaria, v.3, p.215-223, 2012. https://doi.org/10.17268/sci.agropecu.2012.03.03

Cunha, J. P. A. R.; Zandbergen, H. P. Perdas na colheita mecanizada da soja na região do Triângulo Mineiro e Alto Paranaíba, Brasil. Biosciense Journal, v.23, p.61- 66, 2007.
EMBRAPA - Empresa Brasileira de Pesquisa Agropecuária. Perdas na colheita de soja. 2017. Disponível em: <http://blogs.canalrural. com.br/embrapasoja/2017/01/27/ perdas-na-colheita-de-soja/ >. Acesso em: Jun. 2017.

Gobbi, F. T.; Zandonadi, R. S.; Pinto, F. de A. Desempenho de colhedoras de grãos utilizando plataforma de corte com condutor helicoidal e esteira transportadora. In: Congresso Brasileiro de Engenharia Agrícola, 43, 2014, Campo Grande. Anais... Campo Grande: SBEA, 2014.

Gomes, F. P.; Garcia, C. H. Estatística aplicada a experimentos agronômicos e florestais: Exposição com exemplos e orientações para uso de aplicativos. Piracicaba: FEALQ, 2002. 309p.

Holtz, V.; Reis, E. F. dos. Perdas na colheita mecanizada de soja: Uma análise quantitativa e qualitativa. Revista Ceres, v.60, p.347-353, 2013. https://doi.org/10.1590/S0034-737X2013000300007

Loureiro Júnior, A. M.; Silva, R. P. da; Cassia, M. T.; Compagnon, A. M.; Voltarelli, M. A. Influence of the sample area in the variability of losses in the mechanical harvesting of soybeans. Engenharia Agrícola, v.34, p.76-85, 2014. https://doi.org/10.1590/S010069162014000100009

Nietiedt, G. H.; Schlosser, J. F.; Boller, W. Draper hiflex. Cultivar Máquinas, v.106, p.26-30, 2011.

Ormond, A. T. S.; Voltarelli, M. A.; Paixão, C. S. S.; Gírio, L. A. da S.; Zerbato, C.; Silva, R. P. da. Características agronômicas da soja em semeadura convencional e cruzada. Revista Agro@mbiente On-line, v.9, p.414-422, 2015.

Paixão, C. S. S.; Chrispin, C. P.; Silva, R. P.; Girio, L. A. S.; Voltarelli, M. A. Physical and physiological quality of soybean seeds at three speeds of the harvester. Revista Brasileira de Engenharia Agrícola e Ambiental, v.21, p.214-218, 2017. https://doi.org/10.1590/18071929/agriambi.v21n3p214-218

Santos, A. F. dos; Silva, R. P. da; Tavares, T. O.; Ormond, A. T. S.; Rosalen, D. L.; Assis, L. C. de. Parallelism error in peanut sowing operation with auto-steer guidance. Revista Brasileira de Engenharia Agrícola e Ambiental, v.21, p.731-736, 2017. https:// doi.org/10.1590/1807-1929/agriambi.v21n10p731-736

Silva, R. P. da; Cassia, M. T.; Voltarelli, M. A.; Compagnon, A. M.; Furlani, C. E. A. Qualidade da colheita mecanizada de feijão (Phaseolus vulgaris) em dois sistemas de preparo do solo. Revista Ciência Agronômica, v.44, p.61-69, 2013. https://doi.org/10.1590/ S1806-66902013000100008

Tavares, T. de O.; Santinato, F.; Silva, R. P. da; Voltarelli, M. A.; Paixão, C. S. S.; Santinato, R. Qualidade do recolhimento mecanizado do café. Coffee Science, v.10, p.455-463, 2015.

Toledo, A. de; Tabile, R. A.; Silva, R. P. da; Furlani, C. E. A.; Magalhães, S. C.; Costa, B. O. Caracterização das perdas e distribuição de cobertura vegetal em colheita mecanizada de soja. Engenharia Agrícola, v.28, p.710-719, 2008. https://doi.org/10.1590/S010069162008000400011 